\title{
Determination of Bankometer and RGEC Models to Predict Financial Distress on Sharia Banks in Indonesia
}

\author{
Laely Aghe Africa \\ \{laely.aghe@perbanas.ac.id\} \\ STIE Perbanas Surabaya
}

\begin{abstract}
Banking is a collection of several functions of the Bank, which is a financial institution that has financial assets as its wealth and has profit motives and social. Banking institutions also do not rule out the possibility of experiencing financial distress; financial distress is declining phases that happen before liquidation. This research aimed to analyze the Bankometer, and RGEC Model can be used to predict financial distress on Sharia Banks in Indonesia. This research is a quantitative study using 110 financial report data and using logistic regression for analyzing the data. The results show that the Bankometer Model can be used to predict financial distress and RGEC model can be used are the variable NPL, GCG, ROA, and CAR. This research implies that it can be used by Sharia banking determining policies for an early warning before the bankruptcy of a company to avoid liquidation.
\end{abstract}

Keywords: Bankometer, RGEC, Financial Distress, Sharia Banks

\section{Introduction}

The decline in the economy in Indonesia in mid-2018 was caused by several factors, both from internal and external factors. Increasing the dollar has caused some companies to go bankrupt, for example, the company that receives the direct result is a banking company, where banks must prepare banking regulations internally to cope with the increasing dollar. Not for Sharia Banks, Islamic banks will not change credit agreements in borrowing mortgages (home ownership loans and motor vehicle loans), even though the economy in Indonesia has decreased. This has been adjusted to the Sharia Bank policy in general.

Banking is a collection of several functions of the Bank, which is a financial institution that has financial assets as its wealth and is profit-motivated and social [1]. One of the main capital that the Bank is said to be healthy if the bank is spared from the condition of Financial Distress is a condition where the company will experience bankruptcy and given a signal that the company will go bankrupt. Several ways are widely used to determine whether the company is experiencing financial distress or not. One model that can be used is the RGEC (Risk Profile, GCG, Earnings, Capital) model, which includes the Risk Profile element proxied by NPF and FDR, GCG elements proxied by the Composite GCG Self Assessment Value, Earnings element proxied by ROA and Capital elements proxied by CAR. While the Bankometer model

In the 2015 period, Islamic Banking experienced a very drastic decline of 7.98 percent as of July 2015 , whereas in the previous year, it was able to reach 49 percent in 2003 . This is partly 
due to the increase in the ratio of non-performing financing and the decline in the percentage of financing from the bank to the public.

The inconsistency of the results of some of the previous studies that form the basis of this research is essential to do, some previous research shows that GCG and ROA affect Financial Distress [2], NPL influences Financial Distress [3]. the NPL ratio can be used to predict Financial Distress [4], and CAR can be used to predict Financial Distress [5]. Although there are studies that CAR, GCG, LDR, and NPL did not affect the condition of the Financial Distress [6], NPL and LDR affected Financial Distress [7], whereas the CAR, NPL and LDR ratio did not affect Financial Distress [8]. One of the studies regarding the application of the Bankometer Model in Islamic Banking and Conventional Banking companies, the results of which showed that the Bankometer Model could be used to predict Financial Distress [9].

Moreover, the Bankometer model can be used in banking companies, especially Foreign Exchange Banks and Non-Foreign Exchange Banks [10]. Therefore, the results of this research are expected to provide additional knowledge in the field of accounting, especially in the field of financial and banking accounting. Based on the background description above, the researchers are interested in researching the Bankometer Model and RGEC as a model for predicting Financial Distress in Islamic Banks in Indonesia.

\section{Method}

Quantitative research is used in this study, where the data used is secondary data. Characteristics of Quantitative Research include describing problems through trend descriptions or the need to explain the relationship between variables, giving literature an important role in developing research questions, justifying research questions, research goals and hypotheses, analyzing trends, comparing groups or relationships between variables, using statistical analysis and interpretation of results by comparing with the results of previous studies [11], [12]. While secondary data is information collected by others, not by researchers in carrying out research, several secondary data sources include books, journals, government publications on economic indicators, census data, general statistics, media, and company annual reports (Ghozali, 2016: 94). The population of this study is Islamic banks in Indonesia which are listed on the Indonesia Stock Exchange (www.idx.go.id) between 2014 and 2018. The criteria for taking samples in this study include: banking companies are listed as active on the Indonesia Stock Exchange between 2009 - 2018, and a total of approximately 11 Islamic Banks, Sharia Banks that have published the full Financial Statements for the period 2009 to 2018 on the website, Sharia banks that do not conduct mergers, do not experience acquisitions and or restructuring during the year of the study period.

Data collection in this study belongs to the secondary data category obtained from audited Annual Financial Reports obtained from the Bank Indonesia website (www.bi.go.id) and Indonesia Stock Exchange ( $w w w . i d x . c o . i d$ ), period Data collection is for five consecutive years between 2014 and 2018. The technique in collecting data is the documentation method, namely by collecting all financial report data obtained. Data obtained from the above sources, the next step is to process the data, and the results will be interpreted in the form of the results of descriptions, drawings, and tables.

Based on the presentation of several previous theories and materials, the researcher described them through the framework in the following picture: 


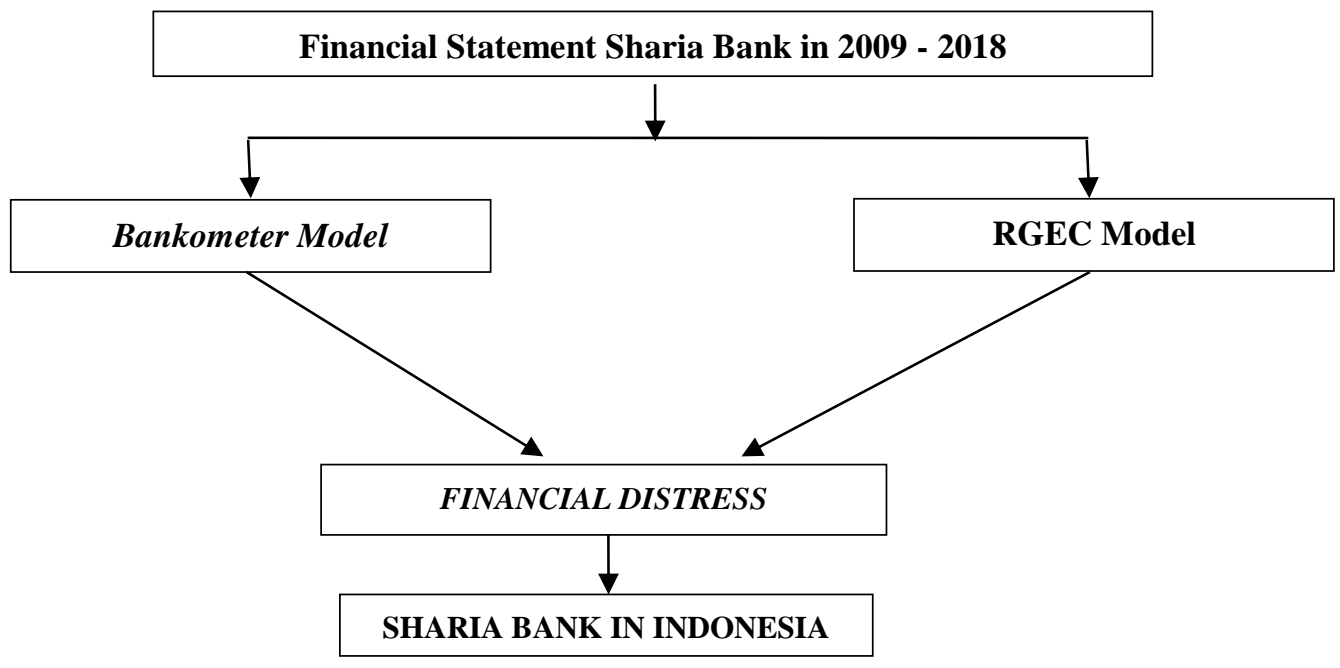

Fig 1. Research Framework

Based on the theoretical basis and framework of thinking, the following steps in the logistic regression analysis used in this study include:

\section{a. Assess the Fit Model}

The first step is to assess the overall fit model of the data, following the steps:

1. Likelihood Function

The statistics used are based on the function of likelihood. Likelihood $\mathrm{L}$ of the model is the probability that the hypothesized model describes input data. To test the null and alternative hypotheses, $\mathrm{L}$ is transformed into $-2 \log \mathrm{L}$.

2. Cox and Snell's R Square and Negelkerke's R Square

Cox and Snell's R Square is a measure that tries to replicate the size of $\mathrm{R}^{2}$ on multiple regression based on estimation techniques with a maximum value of less than 1 (one) so that it is difficult to interpret. Negelkerke's R Square is a modification of the Cox and Snell's $\mathrm{R}^{2}$ coefficients with their maximum values and varies with a value of 0 (zero) to 1 (one). This is done by dividing the Cox and Snell's $\mathrm{R}^{2}$ values by their maximum values. This model is used to find out how the variability of the independent variable can explain much variability of the dependent variable. Negelkerke's $\mathrm{R}^{2}$ values can be interpreted as $\mathrm{R}^{2}$ at multiple regression.

3. Hosmer and Lemeshow's Goodness of Fit test

The Hosmer and Lemeshow's Goodness of Fit test tests the null hypothesis that there are empirical data suitable or by the model. If the Hosmer and Lemeshow's Goodness of Fit test statistics are higher than 0.05 , then the null hypothesis cannot be rejected and means that the model can predict the value of its observations or it can be said that the model is acceptable because the model matches the observations.

a.Hypothesis testing

\section{b. Hypothesis testing}

The results of this research hypothesis must be examined by comparing the probability values (sig). If you see a significant number smaller than 5\%, the regression coefficient is significant at the level of $5 \%$, meaning that $\mathrm{H} 0$ is rejected, which means that the independent variable has a significant effect on the dependent variable. Vice versa, if the number of signatures is higher 
than 0.05 or $5 \%$, it means that $\mathrm{H} 0$ is accepted and $\mathrm{H} 1$ is rejected, which means that the independent variable does not significantly influence the occurrence of the dependent variable. 3. Make conclusions by comparing the results obtained with theories and previous research.

Logistic Regression Statistic analysis that will be applied in this study, with the regression equation as follows:

\section{a. RGEC Model}

$$
\mathrm{Y} 1=\mathrm{b} 0+\mathrm{b} 1(\mathrm{NPL})+\mathrm{b} 1(\mathrm{LDR})+\mathrm{b} 1(\mathrm{GCG})+\mathrm{b} 1(\mathrm{ROA})+\mathrm{b} 1(\mathrm{CAR})+\mathrm{e}
$$

Note:

$\begin{array}{ll}\text { Y } & \text { : Financial Distress } \\ \text { b0 } & \text { : Constanta } \\ \text { b1...b8 } & : \text { Regression Constanta } \\ \text { NPL } & : \text { Non Performing Loan } \\ \text { LDR } & : \text { Loan To Deposit Ratio } \\ \text { GCG } & : \text { Good Corporate Governance } \\ \text { ROA } & : \text { Return On Asset } \\ \text { CAR } & : \text { Capital Adequacy Ratio } \\ \text { e } & \text { : Error }\end{array}$

b. Bankometer Model

$$
\mathrm{Z} 1=\alpha+\beta_{1} \text { Bankometer } \mathrm{e}
$$

Note:

$\begin{array}{ll}\mathrm{Z} & : \text { Financial Distress } \\ \alpha & : \text { Constanta } \\ \beta 1 \text { Bankometer } & : \text { Bankometer Model } \\ \mathrm{e} & : \text { Error }\end{array}$

Definition of Financial Distress according to Platt and Platt (2002) in Africa L.A (2016), Financial Distress is a stage of decline in financial conditions that occur before the occurrence of bankruptcy or liquidation. The usefulness of information if a company experiences Financial Distress are: (1) can accelerate management actions to prevent problems before bankruptcy, (2) management can take mergers or take over actions so that companies are better able to pay debts and manage companies to be better, and (3) provide a warning sign of the beginning of bankruptcy in the future [13]. The dependent variable in this study is Financial Distress, defining financial distress is a condition where the company's finances are in an unhealthy or crisis [4]. Companies that experience financial distress can be seen in the condition of financial statements that show negative net income. Financial distress is measured using a dummy variable with binomial size, which is the value of one (1) if the company experiences financial distress. Value zero (0) if the company does not experience financial distress.

Code 1 , the company experiences financial distress. If changes in equity value, changes in the value of ROA and changes in the value of NIM in banking companies are below or equal to the median value of all observations. Code 0 , the company does not experience financial distress 
if changes in equity value, changes in the value of ROA and changes in the value of NIM in banking companies are above the median value of all observations.

RGEC (Risk Profile, GCG, Earnings, Capital) Model, Commercial Bank Health Assessment is regulated in Bank Indonesia Regulation Number 13 / PBI / 2011 concerning using a risk-based approach known as RGEC which stands for Risk Profile, GCG, Earning, Capital), valuation with the RGEC model is a development of the CAMELS model, This composition in RGEC varies because it incorporates GCG factors into the model. One part of the Risk Profile is a credit risk, where the credit risk that will be used as a reference in this study and the two financial ratios used are NPF and FDR. While GCG is proxied by the results of the Self Assessment on the implementation of GCG. Earnings are proxied by Rentabiltas financial ratio, namely ROA, while Capital is proxied by the financial ratio of Capital, namely CAR. The following are the descriptions of several variables used in this study, among others

\section{a. NPF (Non-Performing Finance)}

Non-performing loans are a ratio that measures how much non-performing loans are compared to the total loans. Non-performing loans are a combination of values from several loans classified as collectibility 3 which run smoothly, collectibility 4 which means doubtful and collectibility 5 .

$$
N P F=\frac{\text { Credit Col } 3,4,5}{\text { Total Credit }} \times 100 \%
$$

\section{b. FDR (Finance To Deposit Ratio)}

Finance to Deposit Ratio is used to assess the extent to which banks can fulfill the maturing obligations of the loans disbursed. The formula used to calculate LDR is:

$$
F D R=\frac{\text { Loan }}{\text { Third Party }} \times 100 \%
$$

\section{c. Good Corporate Governance (GCG)}

The GCG factor is predicted from the value or score of the GCG, which is called the Composite Value of Good Corporate Governance Self-Assessment; the following table 1.

Table 1. Composite Value of Good Corporate Governance Self Assessment

\begin{tabular}{ll}
\hline \multicolumn{1}{c}{ Composite } & \multicolumn{1}{c}{ Composite Predicate } \\
\hline Composit Value $<1,5$ & Very Good \\
$1,5<$ Composit Value $<2,5$ & Good \\
$2,5<$ Composit Value $<3,5$ & Enaugh \\
$3,5<$ Composit Value $<4,5$ & Not Good \\
$4,5<$ Composit Value $<5$ & Bad \\
\hline
\end{tabular}

\section{d. ROA (Return On Asset)}

Return on Assets is used to assess the extent to which banks can obtain overall profits. Following is the calculation of ROA.

$$
R O A=\frac{\text { Profit Before Tax }}{\text { Average Total Assets }} \times 100 \%
$$




\section{e. CAR (Capital Adequacy Ratio)}

Understanding of Capital Adequacy Ratio is to measure the extent to which funds finance all bank assets that contain risks from the bank's capital in addition to getting funds from sources outside the bank. The following calculation from CAR:

ATMR: Weigh Asset By Risk

$$
C A R=\frac{\text { Capital }}{\text { ATMR }} \times 100 \%
$$

\section{Model Bankometer}

The model used to calculate the value in the Bankometer Model has been determined as follows :

$$
\text { S-Score }=1.5(\mathrm{CA})+1.2(\mathrm{EA})+3.5(\mathrm{CAR})+0.6(\mathrm{NPL})+0.3(\mathrm{CIR})+0.4(\mathrm{LA})
$$

Keterangan :

CA : Capital to Asset Ratio = Capital / Asset

EA : Equity to Asset Ratio = Ekuitas / Aset

CAR : Capital Adequacy Ratio

NPL : Non Performing Loan Ratio

CIR : Cost to Income Ratio $=($ Operational Cost $/$ Operational Income $) \times 100 \%$

LA : Loans to Asset Ratio $=($ Credit Total / Asset Total $) \times 100 \%$

S-Score $\quad=$ Score for Insolvent dan Solvent

$=$ Score $<50=$ Insolvent

$=$ Score $>70=$ Solvent

$=$ score $50<\mathrm{S}$-Score $<70=$ Grey Area

Grey Area with criteria, $\mathrm{CA}>4 \%$; EA $>2 \%$; CAR $>8 \%$

$=\mathrm{NPL}<15 \% ;$ CIR $<40 \%$ and LA $<65 \%$.

\section{Result And Discussion}

The final total sample from 2009 to 2018 is 110 data and names of Islamic banks are table 2.

Table 2. Sharia Banks

\begin{tabular}{cl}
\hline No & \multicolumn{1}{c}{ Banks } \\
\hline 1 & PT. BANK SYARIAH MANDIRI \\
2 & PT. BANK SYARIAH MUAMALAT INDONESIA \\
3 & PT. BANK SYARIAH BNI \\
4 & PT. BANK SYARIAH BRI \\
5 & PT. BANK SYARIAH MEGA INDONESIA \\
6 & PT. BANK JABAR DAN BANTEN \\
7 & PT. BANK PANIN SYARIAH \\
8 & PT. BANK SYARIAH BUKOPIN \\
9 & PT. BANK VICTORIA SYARIAH \\
\hline
\end{tabular}




\begin{tabular}{ll}
10 & PT. BCA SYARIAH \\
11 & PT. MAYBANK INDONESIA SYARIAH \\
\hline
\end{tabular}

Table 3. Testing of Model Fit Sharia Banks Model Bankometer

\begin{tabular}{cc}
\hline Model Fit Test & Result \\
\hline$-2 \log$ Likelihood & \\
Block 0 & 64.332 \\
Block 1 & 57.114
\end{tabular}

Snell R Square and Nagelkerke R

Square

\begin{tabular}{|c|c|c|}
\hline & Cox and Snell R Square & 0.178 \\
\hline & Nagelkerke R Square & 0.451 \\
\hline Hosmor & Lemeshow's & \\
\hline \multicolumn{3}{|c|}{ Goodness Of Fit Test } \\
\hline & Chi-Square & 12.334 \\
\hline & Significant & 0.059 \\
\hline \multicolumn{3}{|c|}{ Classification Table } \\
\hline & Total Percentage & 86.0 \\
\hline
\end{tabular}

Table 4. Testing of Model Fit Sharia Banks Model RGEC

\begin{tabular}{|c|c|}
\hline Model Fit Test & Result \\
\hline \multicolumn{2}{|l|}{$-2 \log$ Likelihood } \\
\hline Block 0 & 63.102 \\
\hline Block 1 & 52.257 \\
\hline \multicolumn{2}{|l|}{$\begin{array}{l}\text { Snell R Square and Nagelkerke R } \\
\text { Square }\end{array}$} \\
\hline Cox and Snell R Square & 0.214 \\
\hline Nagelkerke R Square & 0.484 \\
\hline Lemeshow's & \\
\hline \multicolumn{2}{|l|}{ Goodness Of Fit Test } \\
\hline Chi-Square & 11.182 \\
\hline Signifikasi & 0.068 \\
\hline \multicolumn{2}{|l|}{ Classification table } \\
\hline Total Precentage & 91.0 \\
\hline
\end{tabular}

Table 5. Result Sharia Banks Bankometer Models

\begin{tabular}{ccccc}
\hline Variable & Koefisien (B) & Wald & Sig. & Exp (B) \\
\hline Bankometer Syariah & 0.035 & 3.461 & 0.032 & 0.764 \\
\hline
\end{tabular}


Table 6. Result Sharia Banks Model RGEC

\begin{tabular}{lll}
\hline \multicolumn{1}{c}{ Variables } & \multicolumn{1}{c}{ Coefficient $(B)$} & Sign \\
\hline$N P F$ & 0.098 & 0.032 \\
$F D R$ & 0.327 & 0.344 \\
$G C G$ & 0.067 & 0.037 \\
$R O A$ & -0.067 & 0.019 \\
$C A R$ & -0.056 & 0.011 \\
\hline
\end{tabular}

\subsection{Hypothesis 1}

Based on Table 4.4 Regression Results from the RGEC Model, it is known that the NPF variable has a coefficient of 0.098 and a significance value of 0.032 and $0.032<0.05$, so it can be concluded that NPF variables have a significant effect on Financial Distress variables. So thus the first hypothesis (H1) which assumes that the NPL variable can be used to predict the Financial Distress in Islamic Banks is accepted.

\subsection{Hypothesis Testing 2}

Based on Table 4.4 Regression Results from the RGEC Model, it is known that the FDR variable has a coefficient of 0.327 and a significance value of 0.344 and $0.3442>0.05$, so it can be concluded that the FDR variable does not affect the Financial Distress variable. So thus the second hypothesis (H2) assumes that the LDR variable can be used to predict Financial Distress in Islamic Banks in Indonesia.

\subsection{Hypothesis Testing 3}

Based on Table 4.4 Regression Results from the RGEC Model, it is known that the GCG variable has a coefficient of 0.067 and a significance value of 0.037 and $0.037<0.05$, so that it can be concluded that the GCG variable has a significant effect on Financial Distress variables. So thus the third hypothesis (H3) which assumes that the GCG variable can be used to predict the Financial Distress in Islamic Banks is accepted.

\subsection{Hypothesis Testing 4}

Based on Table 4.4 Regression Results from the RGEC Model, it is known that the ROA variable has a coefficient of -0.067 and significance value of 0.019 and $0.019<0.05$, so it can be concluded that the ROA variable significantly influences the Financial Distress variable. So thus the fourth hypothesis (H4) assumes that the ROA variable can be used to predict the Foreign Exchange Bank Distress received.

\subsection{Hypothesis Testing 5}

Based on Table 3.3 Results of Regression for Foreign Exchange Banks, it is known that the CAR variable has a coefficient of -0.056 and significance value of 0.011 and $0.011<0.05$, so that it can be concluded that the CAR variable significantly influences the Financial Distress variable. So thus the fifth hypothesis (H5) assumes that the CAR variable can be used to predict Financial Distress on Islamic Banks in Indonesia.

\subsection{Hypothesis Testing 6}

Based on Table 4.3 Regression Results of the Bankometer Model, it is known that the Bankometer variable has a coefficient of 0.035 and a significance value of 0.032 and 0.032 $<0.05$, so that it can be concluded that the Bankometer affects financial distress. So thus the fifth hypothesis (H6) which assumes that the Bankometer Model can be used to predict Financial Distress in Islamic Banks in Indonesia is accepted.

\section{REASON}




\section{Conclusion}

The final result of this study is that the Bankometer Model can be used to predict financial distress conditions in Islamic banks in Indonesia as indicated by the NPF, GCG, ROA and CAR variables which have a significant effect, and the second result is that the Bankometer Model can be used to predict financial conditions distress in Islamic banks in Indonesia. The total data used is 110 financial report data consisting of 11 Sharia Commercial Banks in Indonesia in 10 years, namely 2009 to 2018. The 2009 election was based on the consideration that in 2009 the Islamic Commercial Banks in Indonesia was officially opened for 11 banks. The implication of this research is that it can be used as a benchmark in the management of banking companies in formulating that using the RGEC model represented by five ratios can be used to predict financial distress, except the FDR ratio. Moreover, the Bankometer model can also be used to predict financial distress conditions in Islamic Commercial Banks in Indonesia. The limitations of this study are the total study population of only 110 financial data of the Bank with the period 2009 to 2018, and the whole is a Sharia Commercial Bank in Indonesia. Suggestions this research is about the limitations, in this study the suggestions that can be given to the next researcher are, among others, (1) extending the research period, (2) expanding the research sample.

\section{References}

[1] M. Hasibuan, Dasar Dasar Perbankan. Jakarta: Bumi Aksara, 2004.

[2] N. M. M. Andari dan I. G. B. Wiksuana, "RGEC sebagai Determinasi dalam Menanggulangi Financial Distress pada Perusahaan Perbankan di Bursa Efek Indonesia," E-Jurnal Manaj. Unud, vol. 6, no. 1, hal. 116-145, 2017.

[3] A. S. Messai dan M. I. Gallali, "Financial leading indicators of banking distress: A micro prudential approach - Evidence from Europe," Asian Soc. Sci., vol. 11, no. 21, hal. 1-13, 2015.

[4] L. A. Africa, "Financial distress for bankruptcy early warning by the risk analysis on go-public banks in Indonesia," J. Econ. Bus. Account. Ventur., vol. 19, no. 2, hal. 259, 2017.

[5] R. I. Siregar dan S. Fauzie, "Analisis Manfaat Rasio Keuangan Dalam Memprediksi Financial Distress Pada Perbankan (2007-2012)," J. Ekon. dan Keuang., vol. 2, no. 12, hal. 716-726, 2012.

[6] F. S. Dewi, R. Arifati, dan R. Andini, “Analysis Of Effect of CAR, ROA, LDR, COMPANY SIZE, NPL, And GCG To Bank Profitability (Case Study On Banking Companies Listed In BEI Period 2010-2013)," J. Account., vol. 2, no. 2, hal. 1-17, 2016.

[7] S. B. Hermanto, "Rahmania, M. F., \& Hermanto, S. B. (2014). Analisis Rasio Keuangan Terhadap Financial Distress Perusahaan Perbankan Studi Empiris di BEI 2010-2012. Jurnal Ilmu dan Riset Akuntansi, 3(11), 1-20.," J. Ilmu dan Ris. Akunt., vol. 3, no. 11, hal. 1-20, 2014.

[8] L. N. Hidayati, "Pengaruh Kecukupan Modal (CAR), Pengelolaan Kredit (NPL), Dan Likuiditas Bank (LDR) Terhadap Probabilitas Kebangkrutan Bank (Studi Pada Bank Umum Swasta Devisa Yang Tercatat Di Bei Tahun 2009 - 2013)," J. Ilmu Manaj., vol. 12, no. 1, hal. 38-50, 2015.

[9] N. Laila dan F. Widihadnanto, "Financial distress prediction using Bankometer model on Islamic and conventional banks: Evidence from Indonesia," Int. J. Econ. Manag., vol. 11, no. S1, hal. 169-181, 2017.

[10] L. A. Africa, "Bankometer Models for Predicting Financial Distress in Banking Industry," $J$. Keuang. dan Perbank., vol. 22, no. 2, hal. 373-379, 2018.

[11] I. Ghozali, Desain Penelitian Kuantitatif Dan Kualitatif Untuk Akuntansi, Bisnis Dan Ilmu Sosial Lainnya. Semarang: Yoga Pratama, 2016. 
[12] J. W. Creswell, Research Design Qualitative, Quantitative, and Mixed Second Edition. 2012.

[13] H. D. Platt dan M. B. Platt, "Understanding Differences between Financial Distress and Bankruptcy,” Rev. Appl. Econ., vol. 2, no. 2, hal. 141-157, 2006. 